Terang U.H.G.M. et al. IbM Penyediaan Sumber Air Bersih Untuk Kebutuhan Rumah Tangga Masyarakat...

\title{
IbM PENYEDIAAN SUMBER AIR BERSIH UNTUK KEBUTUHAN RUMAH TANGGA MASYARAKAT KURANG MAMPU DI DUSUN II DESA BAGAN KUALA KECAMATAN TANJUNG BERINGIN KABUPATEN SERDANG BEDAGAI
}

\author{
Terang U.H.G.M. ${ }^{1}$, Taufiq Bin Nur ${ }^{1}$ \\ ${ }^{1}$ Departemen Teknik Mesin Fakultas Teknik Universitas Sumatera Utara Jl. Almamater Kampus USU \\ Medan - 20155, Telp/Fax. 061-8213250 e-mail :
}

\begin{abstract}
Abstrak
Kebutuhan akan air bersih bagi kehidupan manusia merupakan suatu kebutuhan primer. Manusia tidak akan dapat hidup dengan sehat tanpa adanya air bersih, karena tubuh manusia sangat membutuhkan air, kandungan air di tubuh manusia tidak kurang dari $70 \%$ dari bobot tubuhnya (orang dewasa). Air berfungsi untuk mentransportasi mineral, vitamin, protein dan zat gizi lainnya ke seluruh tubuh. Keseimbangan suhu tubuh akan sangat tergantung pada air, karena air merupakan pelumas jaringan tubuh sekaligus bantalan sendi-sendi, tulang, dan otot. Begitu pentingnya air bagi kelangsungan hidup manusia sehingga ketersediaan dan keberlangsungan air bagi makhluk hidup harus tetap dijaga.Di dalam kehidupan masyarakat modern di Indonesia saat ini, suplai air bersih untuk suatu komunitas masyarakat biasanya dipasok oleh perusahaan-perusahaan air bersih milik pemerintah daerah. Tetapi karena keterbatasan jaringan atau kapasitas produksi seringkali tidak semua komunitas masyarakat tersebut dapat menikmati fasilitas air bersih tersebut. Terutama masyarakat miskin yang hidup di pinggiran atau di luar kota, sehingga mereka terpaksa memanfaatkan sumber-sumber air yang kurang layak digunakan karena tidak higienis. Desa Bagan Kula Kecamatan Tanjung Beringin merupakan salah satu kecamatan yang terdapat di di pesisir pantai. Secara secara administrasi pemerintahan termasuk wilayah kabupaten Serdang Bedagai. Kondisi geografis yang dekat dengan laut menyebabkan desa Bagan Kuala ini sering mengalami kekurangan air bersih karena air permukan yang tersedia merupakan jenis air payau. Sebagai masyarakat mensiasati permasalahan ini dengan melakukan pengeboran yang kedalamannya bisa mencapai 100 meter. Dalamnya pengeboran yang harus dilakukan untuk mendapatkan air tawar dan bersih tersbut menyebabkan biaya membuat sumur bor sangatlah mahal untuk kalangan masyarakat miskin yang sebagian besar berprofesi sebagai buruh nelayan sehingga sering dijumpai banyak masyarakat menggunakan air payau untuk kebutuhan MCK mereka dan hal ini sangat tidak baik untuk kesehatan masyarakat tersebut. Melihat permasalahan yang dihadapi oleh masyarakat tersebut maka dicarikan suatu solusi atas permasalahan yang dihadapi dengan membuat suatu fasilitas sumber air bersih yang berasal dari sumur bor untuk mendapatkan air tanah/bersih dan instalasi perpipaan untuk distribusi air bersih bagi kebutuhan masyarakat.
\end{abstract}

kunci : daerah pesisir, penyediaan air bersih, kesehatan 
Terang U.H.G.M. et al. IbM Penyediaan Sumber Air Bersih Untuk Kebutuhan Rumah Tangga Masyarakat...

\section{PENDAHULUAN}

Kabupaten Serdang Bedagai merupakan salah satu Kabupaten yang berada di kawasan Pantai Timur Sumatera Utara. Secara geografis Kabupaten Serdang Bedagai terletak pada posisi $2^{0} 57^{\prime}$ 'Lintang Utara, $3^{0} 16^{\prime \prime}$ Lintang Selatan, $98^{\circ} 33^{\prime \prime}-99^{\circ} \quad 27^{\prime}$ 'Bujur Timur dengan ketinggian berkisar $0-500$ meter di atas permukaan laut. Mata pencaharian dari masyarakat di daerah Sergai antara lain nelayan, bertani yang sebagian besar komoditinya buah-buahan dan sayursayuran, perkebunan seperti karet dan kelapa sawit serta usaha wisata untuk daerah pantai. Umumnya masyarakat yang tinggal di sepanjang pantai, yang berprofesi sebagai nelayan, kondisi kehidupannya masih tergolong keluarga pra-sejahtera. Standar kehidupannya juga masih rendah akibat dari penghasilan yang kecil. Hal ini dapat terlihat dari kondisi sanitasi lingkungan hidupnya kotor.

Dari hasil kunjungan dan pengamatan lapangan serta wawancara langsung dengan beberapa masyarakat yang berdomisili di sepanjang pantai tersebut, masalah yang paling sulit yang mereka hadapi adalah masalah ketersediaan air bersih. Seperti kita ketahui memang banyak air permukaan yang tersedia di daerah ini tetapi karena sangat berdekatan sekali dengan pantai maka air-air permukaan tersebut rasanya payau, dan tidak layak untuk dikonsumsi. Tetapi terkadang karena tidak ada lagi pilihan, masyarakat didaerah ini terpaksa menggunakan air yang rasanya payau tersebut untuk kebutuhan sehari-hari.

\subsection{Permasalahan Mitra}

Permasalahan yang dihadapi masyarakat di Dusun II desa Bagan Kuala, kecamatan Pantai Cermin kabupaten Serdang Bedagai yang menjadi mitra pada pengabdian ini adalah tidak tersedianya sumber air bersih untuk keperluan seharihari, hal ini dikarenakan pemukiman warga yang berjumlah sekitar 150 kepala keluarga ini berada di daerah pantai yang sumber airnya payau. Semua kegiatan mandi cuci dan kakus (MCK) selama ini menggunakan air payau tersebut sehingga tidak sehat. Tim pengabdi dan mitra merumuskan beberapa permasalahan yang dihadapi dan akan dicarikan solusinya, yaitu :

1. Tidak tersedianya sumber air bersih yang layak konsumsi sehingga diperlukan suatu fasilitas sumber air bersih yang dapat dipergunakan warga.

2. Kurangya pemahaman mengenai pentingnya penggunaan air bersih bagi kesehatan dan menghindarkan penggunaan air yang tidak hiegienis sehingga perlu dilakukan penyuluhan.

Terkait dengan permasalahan yang dihadapi mitra seperti yang telah dijelaskan pada bagian sebelumnya maka disusunlah suatu metodologi untuk mengatasinya yaitu melalui kajian literatur, survei lapangan dan desain fasilitas sumber air bersih tersebut. Namun sebelumnya telah dilakukan juga survei untuk mendapatkan data lengkap tentang potensi air tanah di sekitar kecamatan Pantai Cermin Kabupaten Serdang Bedagai. Secara ringkas dapat dinyatakan bahwa solusi yang ditawarkan kepada kelompok STM tersebut adalah menawarkan pembuatan suatu fasilitas sumber air bersih dengan membuat sumur bor beserta peralatan pendukung lainnya yang tujuannya untuk memudahkan masyarakat di desa Bagan Kuala mendapatkan air bersih untuk kebutuhan sehari-hari. 
Terang U.H.G.M. et al. IbM Penyediaan Sumber Air Bersih Untuk Kebutuhan Rumah Tangga Masyarakat...

\section{METODE PELAKSANAAN}

\subsection{Tempat dan Waktu}

Tempat kegiatan pengabdian pada masyarakat ini dilakukan di Dusun II Desa Bagan Kuala Kecamatan Pantai Cermin Kabupaten Serdang Bedagai Provinsi Sumatera Utara. Lama waktu kegiatan mulai dari perencanaan hingga pelaksanaan di lokasi target sekitar 6 (enam) bulan.

\subsection{Pelaksanaan Kegiatan}

Untuk mewujudkan kegiatan tersebut maka dibuat suatu teknik pelaksanaan agar kegiatan yang akan dilaksanakan dapat berjalan sesuai dengan jadwal, terstruktur dan tepat sasaran. Tahap pelaksanaan kegiatan dapat diuraikan sebagai berikut :

1. Melakukan survei literatur dan survei lapangan

2. Mendesain fasilitas sumber air bersih

3. Pelaksanaan pengeboran sumber air sampai mendapat air yang sesuai.
4. Pelaksanaan pemasangan fasilitas sumber air bersih

5. Pemeriksaan kualitas air yang di peroleh dari sumur bor

6. Mengadakan penyuluhan mengenai air bersih dan perawatan instalasi fasilitas air bersih

7. Melakukan serah terima fasilitas sumber air bersih kepada mitra

8. Melakukan penulisan laporan akhir dan publikasi

\subsection{Bahan dan Peralatan}

Perancangan dan pembuatan fasilitas air bersih dilakukan setelah diperoleh datadata dari hasil survey lapangan. Pada daerah ini untuk mendapatkan air bersih yang layak konsumsi diperlukan kedalaman sumur antara (100 - 130)meter. Peralatan dan bahan yang diperlukan untuk membangun fasilitas air bersih ini antara lain dapat dilihat seperti pada Gambar 2.1.

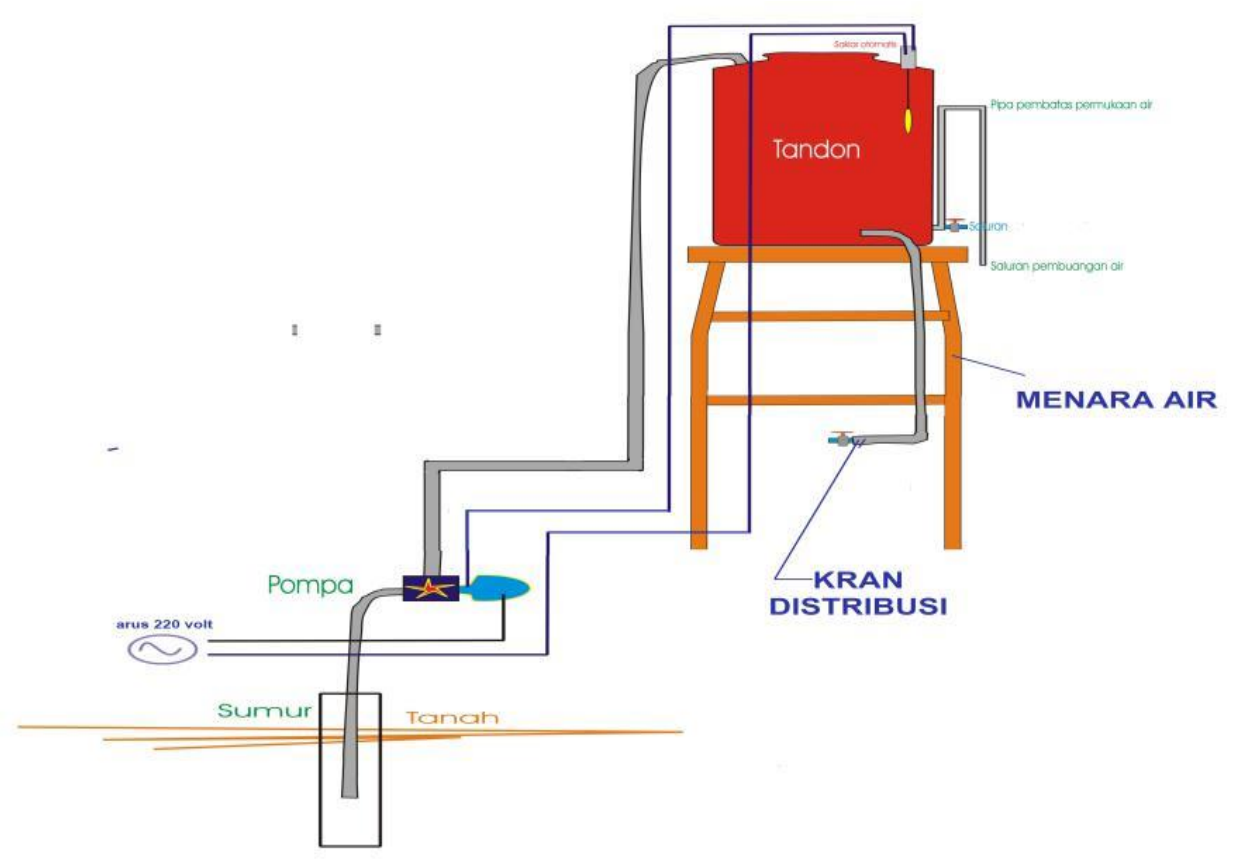

Gambar 2.1. Skema bahan fasilitas air bersih 
Terang U.H.G.M. et al. IbM Penyediaan Sumber Air Bersih Untuk Kebutuhan Rumah Tangga Masyarakat...

\section{Hasil dan Pembahasan Kegiatan}

\subsection{Pembuatan Fasilitas Air Bersih}

Proses pembuatan instalasi fasilitas air bersih untuk masyarakat nelayan di Dususn II Desa bagan Kuala Kecamatan Tanjung Beringin Kabupaten Serdang Bedagai dapat dilihat pada Gambar 2.2.
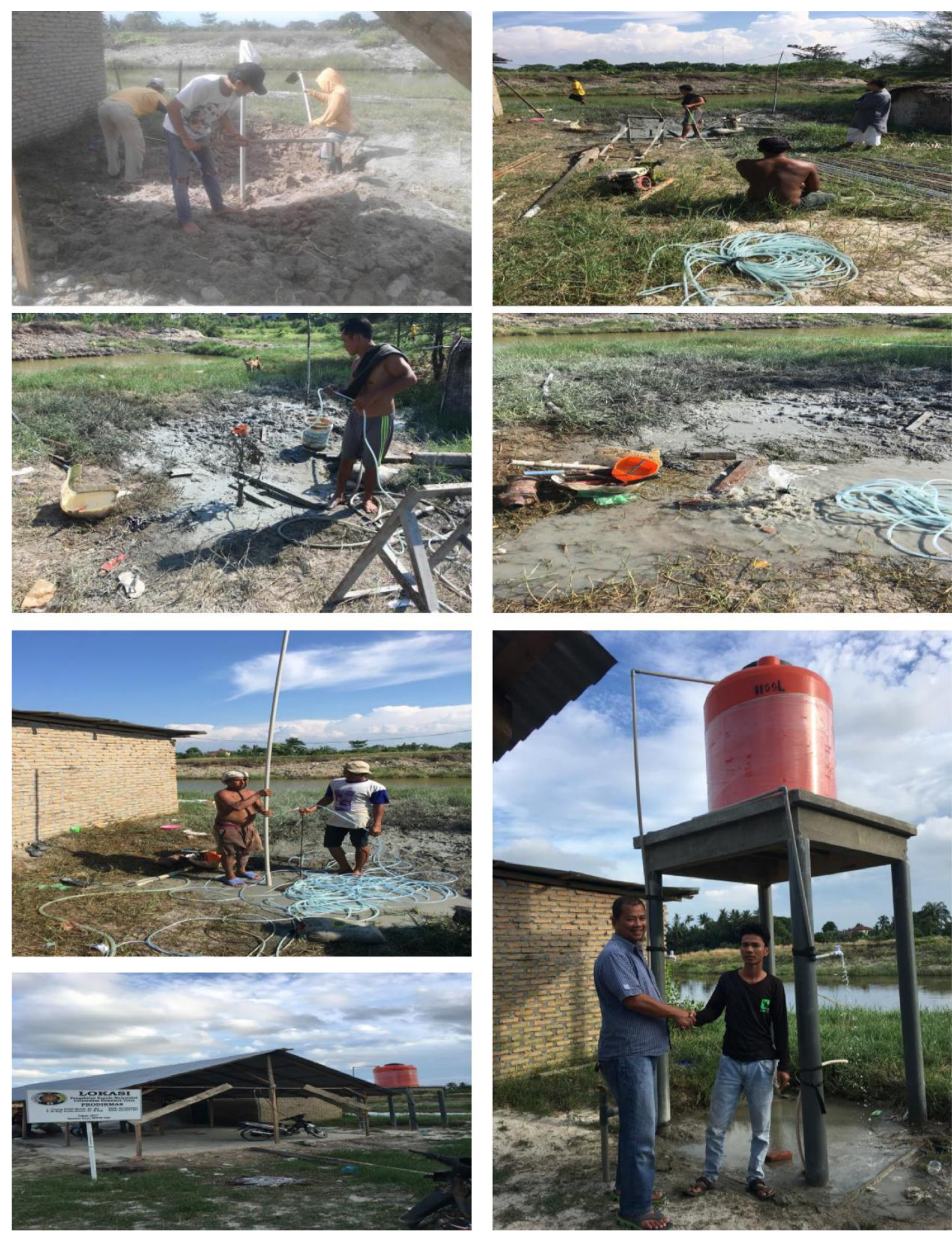

Gambar 2.2. Dokumentasi kegiatan pembuatan fasilitas air bersih 
Terang U.H.G.M. et al. IbM Penyediaan Sumber Air Bersih Untuk Kebutuhan Rumah Tangga Masyarakat...

\subsection{Luaran yang Dicapai}

Luaran yang dicapai dari kegiatan pengabdian pada masyarakat ini adalah suatu fasilitas sumber air bersih yang berasal dari sumur bor dengan kedalaman \pm 120 meter beserta perlengkapannya yang bertujuan untuk memenuhi kebutuhan air bersih sehari-hari dari masyarakat mitra disekitar fasilitas tersebut. Dengan adanya fasilitas ini, masyarakat di sekitar fasilitas ini sangat terbantu sekali karena mereka dapat menggunakan air tawar yang bersih, yang mana selama ini mereka menggunakan air yang rasanya payau. Kontribusi mendasar pada khayalak sasaran yaitu memberikan manfaat pada masyarakat sekitar dalam hal kebutuhan air bersih bagi masyarakat di Dusun II desa Bagan Kuala Kecamatan Pantai Cermin.

Air yang diperoleh cukup bersih (bening) tidak berbau dan hangat. Setelah diuji secara manual dengan metode dan parameter yang sederhana maka air yang didapat dirasa cukup memadai.

Berdasarkan pengamatan di lapangan oleh tim PPM selama kurang lebih satu minggu terhadap penggunaan dan manfaat fasilitas air bersih tersebut dapat dilihat bahwa masyarakat sekitar sangat terbantu sekali dengan adanya fasilitas air bersih tersebut. Hal ini terlihat dari trafik penggunaan yang cukup intens dari masyarakat sekitar, baik untuk kebutuhan rumah tangga maupun untuk keperluan nelayan yang baru pulang dari melaut.

\section{Kesimpulan}

Dari kegiatan yang dilakukan selama lima bulan ini dapat disimpulkan sebagai berikut :
1. Telah dibuat suatu fasilitas sumber air bersih yang bersumber dari sumur bor dengan kedalaman 120 m. Untuk menaikan air digunakan pompa jenis jetpump yang kemudian ditampung pada sebuah tangki air dengan kapasitas 1000 liter dan diletakkan diatas sebuah menara air dengan ketinggian 2,5 meter.

2. Kapasitas dan kualitas air yang didapat cukup baik serta layak untuk kebutuhan mandi, cuci, kakus (MCK) untuk 10 kepala keluarga.

3. Telah dilakukan penyuluhan tentang air bersih dan perawatan fasilitas sumber air bersih yang diikuti masyarakat mitra nelayan disekitar lokasi pengabdian.

4. Kontribusi mendasar pada khayalak sasaran yaitu memberikan manfaat pada mitra masyarakat nelayan disekitarnya dalam hal penyediaan air bersih sehingga meningkatkan tingkat kesehatan masyarakat sekitarnya

\section{Ucapan Terimakasih}

Tim $\begin{gathered}\text { pelaksana } \\ \text { kepada }\end{gathered} \begin{array}{r}\text { kegiatan } \\ \text { masyarakat } \\ \text { mengabdian }\end{array}$ terima kasih $\begin{array}{r}\text { kepada } \\ \text { Univrsitas Sumatera Utara melalui }\end{array}$
Lembaga Pengabdian Pada Masyarakat
(LPPM) atas penyediaan seluruh dana
kegiatan pengabdian pada masyarakat
tahun 2017 sehingga kegiatas diatas dapat
terlaksana.


Terang U.H.G.M. et al. IbM Penyediaan Sumber Air Bersih Untuk Kebutuhan Rumah Tangga Masyarakat...

\section{Daftar Pustaka}

[1] Adhyatma, 1990, Daftar Persyaratan Kualitas Air Bersih, Peraturan Menteri Kesehatan R.I.No. 416/MENKES/PER/IX/1990, September 1990.

[2] Anonimous, 2011, Ironi Air di Indonesia, Sustaining Partnership, Edisi Desember 2011, www.pkps.bappenas.go.id hal.4

[3] Prihatin,R.B., 2013, Problem Air Bersih di Perkotaan, Info
Singkat, Pusat Pengkajian, Penglohan Dan dan Informasi (P3DI) Sekretariat Jenderal DPR RI, ISSN 2088-2351, Vol.V No.7, hal.9-12.

[4] Anonimous, 2007, Medan dalam Angka, Geografism www.pemkomedan.go.id online 13 Oktober 2015.

[5] Anonimous, 2012, Air Bersih, Sanitasi \& Kebersihan, Ringkasan Kajian, UNICEF Indonesia.

[6] Hardi Prasetyo 2013, Gambar konstruksi sumur bor dan pemasangan pompa. 